\title{
HUBUNGAN ANTARA PERSONAL HYGIENE DENGAN KEJADIAN KUSTA DI WILAYAH KERJA PUSKESMAS WONOASRI KABUPATEN MADIUN
}

\author{
Avicena Sakufa Marsanti ${ }^{1}$, Hanifah Ardiani ${ }^{2}$ \\ ${ }^{1-2}$ STIKES Bhakti Husada Mulia Madiun \\ Email: avicena.sm@gmail.com
}

\begin{abstract}
ABSTRAK
Kusta merupakan penyakit menular yang menyerang kulit. Pada Tahun 2018 Kasus Kejadian Kusta di Indonesia kembali meningkat yakni dari 15910 kasus menjadi 17017 kasus. Selama periode tahun 2015-2016 jawa timur merupakan satu-satunya provinsi di bagian barat Indonesia dengan angka beban Kusta tinggi. Sedangkan Kejadian Kusta pada Wilayah Kerja Puskesmas Wonoasri menduduki peringkat ke -2 di Kabupaten Madiun. Penelitian ini bertujuan untuk mengetahui hubungan antara Personal Hygiene dengan Kejadian Kusta. Penelitian Kuantitatif dengan desain penelitian case control, Teknik sampling Simple Random Sampling dengan Jumlah sampel penelitian sebanyak 60 responden yang terdiri dari kelompok kasus dan control. Hasil Penelitian menunjukkan bahwa ada Hubungan antara Personal Hygiene dengan Kejadian Kusta dibuktikan dengan nilai $p$ Value $=0,026 \quad(95 \% \mathrm{CI}=1,320-14,504)$. Personal Hygiene merupakan tindakan pencegahaan individu untuk meningkatkan kesehatan secara mandiri dalam membatasi menyebarnya penyakit menular, terutama yang ditularkan secara langsung dalam hal ini kejadian kusta. Praktek Personal Hygiene yang kurang baik meningkatkan resiko penularan kejadian penyakit kusta.
\end{abstract}

Kata Kunci: Kusta, Personal Hygiene, Penyakit Menular

\section{ABSTRACT}

Leprosy is an infectious disease that attacks the skin. In 2018 cases of leprosy in Indonesia increased again, from 15910 cases to 17017 cases. During the period of 2015-2016 East Java was the only province in the western part of Indonesia with a high leprosy burden. While the Leprosy Occupation in the Wonoasri Community Health Center Work Area moved to 2nd place in Madiun Regency. This study aims to determine the relationship between Personal Hygiene with Leprosy. Quantitative research with case control research design, Simple Random Sampling technique with a total sample of 60 respondents consisting of cases and controls. The results showed that there was a relationship between personal hygiene with leprosy events as evidenced by the $p$ value $=0.026(95 \% C I=1.320-14.504)$. Personal Hygiene is an individual preventive measure to improve independent health in increasing infectious diseases, especially those transmitted directly in the case of leprosy. Poor personal hygiene practices increase the risk of transmission of leprosy. 
Keywords: Leprosy, Personal Hygiene, Infectious Diseases

\section{LATAR BELAKANG}

Penyakit sebagian besar dikaitkan dengan adanya hubungan interaktif antara kehidupan manusia dengan bahan, kekuatan, atau zat yang tidak dikendaki yang datang dari luar tubuhnya. Akibatnya bisa secara langsung menimbulkan gangguan atau mengeluarkan bahan beracun (toxin) dalam tubuh manusia, sehingga mengganggu fungsi ataupun bentuk suatu organ (Achmadi, 2014).

Lingkungan adalah segala sesuatu yg ada disekitarnya (benda hidup, mati, nyata, abstrak) serta suasana yg terbentuk karena terjadi interaksi antara elemen-elemen di alam tersebut. Penyakit Berbasis Lingkungan adalah suatu kondisi patologis berupa kelainan fungsi atau morfologi suatu organ tubuh yang disebabkan oleh interaksi manusia dengan segala sesuatu disekitarnya yang memiliki potensi penyakit (Purnama, 2016).

Penyakit Kusta atau lepra disebut juga Morbus Hansen (MH) sesuai dengan nama yang menemukan kuman. Kusta merupakan penyakit yang disebabkan oleh Mycobacterium leprae. Kusta menyerang bebagai bagian tubuh diantaranya saraf dan kulit. Penyakit ini adalah tipe penyakit granulomatosa pada saraf tepi dan mukosa dari saluran pernafasan atas dan lesi pada kulit adalah tanda yang bisa diamati dari luar. Bila tidak ditangani, kusta sangat progresif menyebabkan kerusakan pada kulit, saraf-saraf, anggota gerak dan mata. Tidak seperti mitos yang beredar di masyarakat, kusta tidak menyebabkan pelepasan anggota tubuh yang begitu mudah seperti pada penyakit tzaraath yang digambarkan dan sering disamakan dengan kusta (Kemenkes RI, 2018).

Kusta dikenal ada dua macam tipe kusta yaitu tipe MB (Multi Basier atau Kusta Basah) dan tipe PB (Pausi Basiler atau Kusta Kering). Penularan kusta secara jelas masih belum diketahui tetapi sebagai besar dari peneliti menyimpulkan bahwa penularan utama kusta yaitu melewati kulit, namun perlu kontak yang akrab dan lama dengan penderita kusta hingga dapat terinfeksi penyakit kusta (Kemenkes RI, 2012).

Penyakit kusta masih menjadi masalah, baik skala global maupun nasional. WHO juga melaporkan bahwa Indonesia menempati jumlah insiden kusta tertinggi nomor 3 di dunia dengan jumlah kasus sebesar (16.826 kasus) setelah India (385.485 kasus) dan Brazil (25.281 kasus). Pada Tahun 2018 Kasus Kusta di Indonesia kembali meningkat yakni sebesar 17017 kasus (WHO, 2019).

Berdasarkan bebannya, kusta dibagi menjadi 2 kelompok yaitu beban kusta tinggi (high Burden) dan beban kusta rendah (low burden). Provinsi disebut high burden jika new case detection rate $(\mathrm{NCDR})>10$ per 100.000 penduduk dan atau jumlah kasus baru lebih dari 1.000. Hampir seluruh proinsi di bagian timur Indonesia merupakan daerah dengan beban kusta tinggi. Selama periode 2015-2016 jawa timur merupakan satu-satunya provinsi di bagian barat Indonesia dengan angka beban Kusta tinggi dimana NCDR pada tahun 2015 sebesar 10,33\% (4.024 jiwa kasus baru), tahun 2016 sebesar 10,23\% (3.999 jiwa kasus baru) dan pada tahun 2017 menjadi 8,58\% (3373 jiwa kasus baru) (Kemenkes RI, 2018). Khususnya Kabupaten Madiun menduduki urutan ke19 dari 54 kasus penyakit kusta di jawa timur. Pada tahun 2017 Kabupaten Madiun mengalami kenaikan dengan angka prevalensi 23 kasus (0,34/ 10.000 penduduk) (Dinas Kesehatan Kabupaten Madiun, 2017). 
Penyakit Kusta di Kabupaten Madiun berada diperingkat teratas yaitu pada Puskesmas Balerejo dan Puskesmas Wonoasri. Peringkat ke-1 diduduki oleh Puskesmas Balerejo dengan 28 kasus (15\%) di tahun 2017 dan 39 kasus (25\%) ditahun 2018. Sedangkan Puskesmas Wonoasri yang menduduki peringkat ke - 2 mempunyai kasus kusta 22 kasus $(13,7 \%)$ di tahun 2017 dan 35 kasus $(22,9 \%)$ di tahun 2018. Peneliti mengambil kasus di wilayah kerja Puskesmas Wonoasri dikarenakan kusta basah lebih banyak dibandingkan kusta kering. Sedangkan, di wilayah kerja Puskesmas Balerejo kusta basah lebih sedikit dibandingkan kusta kering. Sehingga, penularan kusta yang paling beresiko di wilayah kerja Puskesmas Wonoasri (Dinas Kesehatan Kabupaten Madiun, 2017).

Faktor resiko yang berhubungan dengan penyakit kusta adalah Faktor Personal Higiene. Kondisi sehat dapat dicapai dengan mengubah perilaku tidak sehat dan menciptakan lingkungan sehat dirumah tangga. Di wilayah kerja Puskesmas Wonoasri pada kondisi fisik rumah masih banyak yang kurang memenuhi syarat kesehatan. Jumlah rumah tangga yang berperilaku hidup bersih dan sehat 2016 sebanyak 899 (48,7\%) dan 2017 sebanyak 907 (67\%) rumah tangga yang dikatagorikan sebagai rumah tangga yang sehat dari 9.570 rumah yang dipantau. Cakupan rumah pada masyarakat di Wonoasri dalam kategori belum memenuhi syarat dan lebih rendah dari target nasional yaitu 80\% (Depkes RI, 2015). Dapat disimpulkan bahwa pencapaian rumah sehat di Puskesmas Wonoasri belum 100\%, Keadaan ini diduga menjadi perkembangbiakan kuman kusta di dalam rumah dan memungkinkan penularan penyakit dapat berlangsung (Puskesmas Wonoasri, 2017).

Penderita kusta di Wonoasri mayoritas bertempat tinggal satu rumah dengan mereka yang belum terdeteksi penyakit kusta. Sehingga, dengan adanya kontak langsung dengan penderita bakteri Mycobacterium leprae dengan mudah masuk ke tubuh anggota keluarga yang belum terdeteksi penyakit kusta.

Mayoritas Masyarakat Wonoasri bekerja sebagai petani, buruh tani dimana berpenghasilan dibawah UMR Kabupaten Madiun. Hal tersebut, kategorikan bahwa status ekonomi masih rendah. Status ekonomi keluarga yang rendah mempunyai resiko yang lebih besar menderita kusta dibandingkan dengan keluarga yang kondisi ekonominya baik.

Dari permasalahan diatas maka perlu memperhatikan mata rantai penularan penyakit kusta, penyakit kusta dapat diputuskan penularannya melalui intervensi yang sesuai dan hal ini dapat dilakukan jika proses terjadinya infeksi penyakit tersebut diketahui. Penyakit kusta bisa dihentikan bila kondisi lingkungan, riwayat kontak harus diperbaiki dengan tepat. Untuk instansi kesehatan sebaiknya memberikan pelayanan promotif yang berkaitan dengan penyakit kusta seperti memberikan penyuluhan mengenai pentingnya menciptakan dan memelihara rumah sehat serta menjaga kebersihan diri,

\section{METODE PENELITIAN}

Desain penelitian yang digunakan dalam penelitian ini adalah penelitian kuantitatif dengan desain studi Case Control, dimana rancangan penelitian analitik yang mengikuti proses perjalanan penyakit kearah belakang berdasarkan urutan waktu. Oleh karena itu, rancangan penelitian ini disebut restrospektif. Karena penelitian kasus kontrol dilakukan sebab akibat maka penelitian diawali dengan kelompok penderita sebagai kasus dan kelompok penderita sebagai kontrol. 
Populasi kasus ini dalam penelitian ini yaitu semua penderita penyakit kusta yang terdaftar di Puskesmas Wonoasri dan untuk populasi yang tidak terdiagnosis kusta berdasarkan pemeriksaan klinis, sehingga didapatkan jumlah sampel sebanyak 30 sampel, yaitu 30 sampel kasus dan 30 sampel kontrol dengan perbandingan 1:1 sehingga jumlah sampel yang diteliti pada penelitian ini 60 sampel.

Kriteria Inklusi Penelitian pada kelompok kasus yaitu Warga yang telah terdiagnosa penyakit kusta dan terdaftar di Puskesmas Wonoasri Kabupaten Madiun. Sedangkan kriteria inklusi pada kelompok Kontrol, Warga yang tidak terdiagnosa kusta dan tidak terdaftar di Puskemas Wonoasri

Dalam penelitian ini menggunakan probability sampling dengan jenis simple random sampling. Probability sampling adalah adalah teknik pengambilan sampel yang memberikan peluang yang sama bagi setiap unsur (anggota) populasi untuk dipilih menjadi sampel (Sugiyono, 2018).

\section{HASIL DAN PEMBAHASAN}

Kecamatan Wonoasri terletak dengan ketinggian antara 55 meter sampai dengan 68 meter di atas permukaan air laut dan keseluruhan mempunyai topografi yang datar. Luas wilayah Kecamatan Wonoasri adalah 33,93 $\mathrm{km}^{2}$ yang terbagi dalam 10 desa.

Karakteristik responden penelitian di UPT Puskesmas Wonoasri Kabupaten Madiun yang tercakup dalam lembar pertanyaan penelitian meliputi jenis kelamin,pendidikan, dan umur.

\section{Tabel 1}

Karakteristik Responden Penelitian

\begin{tabular}{lll}
\hline Karakteristik & Frekuensi & Persentase (\%) \\
\hline Jenis Kelamin & & \\
Laki - Laki & 23 & 38,3 \\
Perempuan & 37 & 61,7 \\
Pendidikan & & \\
SD & 9 & 15 \\
SMP & 21 & 35 \\
SMA & 30 & 50 \\
Umur & & \\
$\geq 35$ Tahun & 50 & 83,3 \\
$<35$ Tahun & 10 & 16,7 \\
Personal & & \\
Hygiene & & \\
Kurang Baik & 41 & 68,3 \\
Baik & 19 & 31,7 \\
\hline
\end{tabular}

Berdasarkan tabel 1 di atas dapat diketahui bahwa sebagian besar responden berjenis kelamin perempuan yaitu sebanyak 37 orang $(61,7 \%)$, dengan mayoritas pendidikan terakhir SMA sebanyak 30 orang (50\%), berumur $\geq 35$ tahun sebanyak 50 orang $(83,3 \%)$, serta 41 orang $(68,3 \%)$ memiliki personal hygiene kurang baik.

Dalam Epidemiologi kusta, umur seseorang pada saat penularan kusta adalah aspek yang sangat penting. Umur saat penularan terkena kusta diketahui bervariasi di berbagai negara, di berbagai daerah pada suatu negara, dan juga daerah yang sama dari waktu ke waktu (Permenkes RI, 2019). 
Dilihat dari tingkatan pendidikan, dimana Masyarakat yang terdidik lebih memperhatikan ketika mendapati munculnya hipopigmentasi pada kulit dan melaporkan ke dokter dengan segera. Sedangkan pada sisi yang lain, masyarakat yang tinggal dirumah yang miskin mungkin tidak melaporkan untuk memperoleh pendapat dari tenaga kesehatan dalam waktu yang lama karena ketidaktahuan dan ketidak pedulian mereka.

Faktor sosial ekonomi kiranya memegang peranan. Makin rendah sosial ekonominya makin subur kusta dan sebaliknya. Faktor sosial ekonominya tinggi membantu penyembuhan. Penyakit ini kebanyakan terdapat di daerah tropis dan subtropics yang panas dan lembab droplet (Gunawan, Achdiat, \& Rahardjo, 2018).

Tabel 2

Hubungan Personal Hygiene dengan Kejadian Kusta

\begin{tabular}{|c|c|c|c|c|c|c|c|}
\hline \multirow{3}{*}{ Variabel } & \multicolumn{4}{|c|}{ Kejadian kusta } & \multirow{3}{*}{ OR } & \multirow{3}{*}{$95 \% \mathrm{CI}$} & \multirow{3}{*}{$p$-value } \\
\hline & \multicolumn{2}{|c|}{ kasus } & \multicolumn{2}{|c|}{ kontrol } & & & \\
\hline & $\mathrm{N}$ & $\%$ & $\mathrm{~N}$ & $\%$ & & & \\
\hline \multicolumn{8}{|l|}{ Personal Hygiene } \\
\hline Kurang Baik & 25 & 83,3 & 16 & 43,3 & 4,375 & $1,320-$ & 0,026 \\
\hline Baik & 5 & 16,7 & 14 & 46,7 & & 14,504 & \\
\hline
\end{tabular}

Berdasarkan tabel 2 di atas dapat diketahui bahwa persentase responden yang memiliki personal hygiene buruk pada kelompok kasus sebanyak $25(83,3 \%)$, lebih besar dari kelompok kontrol yang hanya 16 (43,3\%). Berdasarkan uji Chi-Square yang sudah dilakukan dilihat (continuity correction) dengan $\mathrm{p}$ Value $0.026<0.05$ berarti ada hubungan antara riwayat kontak dengan kejadian kusta di wilayah kerja Puskesmas Wonoasri Kabupaten Madiun. Dimana responden yang memiliki personal hygiene kurang baik beresiko lebih tinggi $(4,375)$ untuk mengalami kejadian kusta.

Kusta merupakan penyakit infeksius, tetapi derajat infeksitasnya rendah. Kusta memiliki waktu inkubasi panjang, mungkin beberapa tahun dan tampaknya kebanyakan responden mendapatkan infeksi sewaktu masa anak - anak. Insiden yang tinggi pada pasien yang merupakan pasangan suami istri (kusta yang diperoleh dari pasangannya). Penyakit ini timbul akibat kontak fisik yang erat dengan pasien yang terinfeksi dan resiko ini jauh lebih besar bila terjadi kontak dengan kasus kusta (Manyullei, Utama, \& Birawida, 2012).

Manusia merupakan reservoir penularan kuman seperti Mycobacterium leprae, kuman tersebut dapat menularkan pada 10-15 orang. Menurut penelitian pusat ekologi penelitian tingkat penularan kusta di lingkungan keluarga penderita cukup tinggi, dimana seseorang penderita rata-rata dapat menularkan kepada 2-3 orang di dalam rumahnya (Suardi, 2014). Oleh karena itu personal Hygiene host atau pejamu dalam hal ini manusia perlu ditingkatkan dengan perilaku hidup bersih dan sehat.

Personal Hygiene merupakan tindakan pencegahaan yang meliputi tanggung jawab individu untuk meningkatkan kesehatan serta membatasi menyebarnya penyakit menular, terutama yang ditularkan secara langsung. Faktor resiko Personal Hygiene sangat berpengaruh terhadap penularan penyakit kusta diantaranya mandi minimal 2 hari sekali, sering atau tidaknya bertukar pakaian dengan saudara atau teman, kebiasaan pinjam meminjam alat pribadi (handuk, sabun,sisir dll) dengan anggota keluarga lain, menggunakan sikat gigi bersama dengan orang lain, tidak menutup hidung dan mulut saat batuk atau bersin, mencuci tangan Sebelum dan Sesudah makan serta sesudah ke kamar mandi, memotong kuku Secara teratur minimal 1 kali dalam seminggu, dan 
mencuci rambut (keramas) minimal 2 kali seminggu. Penelitian ini sejalan dengan penelitian yang dilakukan oleh rismawati tahun 2013 yakni bahwa ada hubungan antara kebiasaan mandi (Personal Hygiene) dengan kejadian kusta.

Mayoritas responden yang menderita kusta dikarenakan tertular dari penderita lain yaitu keluarga (lama kontak dengan penderita), hal ini sejalan dengan penelitian Benjamin yang meneliti faktor - faktor yang berhubungan dengan kejadian kusta menyatakan bahwa riwayat kontak merupakan faktor risiko kejadian kusta, dikarenakan bahwa kontak dengan penderita yang lama berisiko terhadap kejadian kusta dibandingkan dengan orang yang kontak dengan penderita hanya singkat (Kora, 2016).

Penyakit kusta adalah penyakit menular menahun yang disebabkan oleh M.leprae yang terutama menyerang saraf tepi, kulit dan organ tubuh lain kecuali susunan saraf pusat. Untuk mendiagnosanya mencari kelainan kelainan yang berhubungan dengan gangguan saraf tepi dan kelainan kelainan yang tampak pada kulit (Departemen Kesehatan, 2016).

Penularannya melalui kontak yang lama karena pergaulan yang rapat dan berulang-ulang melalui saluran pernapasan dan kulit (kontak langsung yang lama dan erat), kuman mencapai permukaan kulit melalui folikel, rambut dan keringat. Pencegahan penyakit kusta dapat dilakukan dengan meningkatkan personal hygiene, diantaranya pemeliharaan kulit, pemeliharaan rambut, kebersihan tangan, pakaian dan tempat tidur karena penularan kusta sangat dipengaruhi oleh kontak langsung dengan penderita (Komalaningsih, 2016).

\section{SIMPULAN DAN SARAN \\ Simpulan}

Personal Hygiene merupakan faktor resiko terjadinya kejadian penyakit kusta, hal ini terbukti dengan hasil analisis uji bivariate pada kelompok kasus dan control, didapatkan $p$ value 0.026 , yang berarti ada hubungan antara personal hygiene responden dengan kejadian kusta.

\section{Saran}

Diharapkan masyarakat lebih banyak mendapatkan edukasi atau penyuluhan tentang faktor resiko penyebab penularan penyakit kusta dan selalu menerapkan perilaku hidup bersih dan sehat (PHBS) sehingga dapat menekan penularan kusta dari orang ke orang lain.

\section{UCAPAN TERIMAKASIH}

Seluruh Responden yang telah bersedia ikut serta dalam penelitian ini, Seluruh Dosen (Program Studi Kesehatan Masyarakat) beserta staff dan Yayasan Bhakti Husada Mulia Madiun yang telah mendukung dan membantu demi kelancaran penelitian ini.

\section{DAFTAR PUSTAKA}

Achmadi, U. F. (2014). Manajemen Penyakit Berbasis Wilayah. Jakarta: PT. Raja Grafindo Persada.

Departemen Kesehatan. (2016). "Pedoman Nasional Pemberantasan Penyakit Kusta," Jakarta.

Dinas Kesehatan Kabupaten Madiun. (2017). Profil Penyakit Kusta Pemberantas Penyakit Menular Dinas Kesehatan Kabupaten Madiun,”. 
Gunawan, H., Achdiat, P. A., \& Rahardjo, R. M. (2018). Tingkat pengetahuan penyakit kusta dan komplikasinya pada siswa sekolah menengah atas negeri Jatinangor. Dharmakarya : Jurnal Aplikasi Ipteks untuk Masyarakat. doi: 10.24198/dharmakarya.v7i2.19379.

Kemenkes RI. (2012). Pedoman Nasional Pengendalian Kusta.

Kemenkes RI. (2018). "Hapuskan Stigma dan Diskriminasi terhadap Kusta," in InfoDatin Pusat Data dan Informasi Kementrian Kesehatan RI.

Komalaningsih, S. (2016). "Hubungan Personal Hygiene Dengan Kejadian Penyakit Kusta Di Rumah Sakit Khusus Kusta Dr Sitanala Kota Tangerang Tahun 2015," Jurnal Sehat Masada, vol. X, no. 2, 2016, [Online]. Available: http://ejurnal.stikesdhb.ac.id/index.php/Jsm/article/download/18/5.

Kora, B. (2016). "Faktor Risiko Kejadian Penyakit Kusta Di Wilayah Kerja Puskesmas Saumlaki Kabupaten Maluku Tenggara Barat Tahun 2010-2011," Media Kesehatan Masyarakat Indonesia. doi: 10.30597/MKMI.V9I4.460.

Manyullei, S., Utama, D. A., \& Birawida, A. B. (2012).“Gambaran Faktor Yang Berhubungan Dengan Penderita Kusta Di Kecamatan Tamalate Kota Makassar," Arch. Community Heal.

Permenkes RI. (2019). Peraturan Menteri Kesehatan Republik Indonesia Nomor 11 Tahun 2019 Tentang Penanggulangan Kusta. [Online]. Available: http://hukor.kemkes.go.id/uploads/produk_hukum/PMK_No_11_Th_2019_ttg_ Penanggulangan_Kusta.pdf.

Purnama, S.G. (2016). Buku Ajar Penyakit Berbasis Lingkungan.

Puskesmas Wonoasri. (2017) Profil Kesehatan Puskesmas Wonoasri.

Suardi. (2014). "Faktor-Faktor Yang Berhubungan Dengan Kejadian Penyakit Kusta Di Kabupaten Biak Numfor," Eprints UNDIP, [Online]. Available: http://eprints.undip.ac.id/42543/.

Sugiyono. (2018). Metode Penelitian Kuantitatif,Kualitatif dan R\&D. Bandung: Alfabeta.

WHO. (2019) . Leprosy - Number of new leprosy cases Data by country, Global Health Observatory data repository. https://apps.who.int/gho/data/node.main.A1639. 